УДК 101.1:316

DOI 10.35423/2078-8142.2021.1.2.02

В. О. Коваль,

аспірант кафедри філософії Житомирського державного університету імені Івана Франка, м. Житомир, Україна e-mail:vitalij.koval.kvo@gmail.com ORCID: https://0000-0002-7469-4119

\title{
ДЕСТРУКТИВНИЙ ЗМІСТ РЕКЛАМИ: ОБРАЗИ ТА СИМВОЛИ (СОЦІАЛЬНО-ФІЛОСОФСЬКИЙ АСПЕКТ)
}

Вивчення деструктивного змісту реклами дає нам можливість проаналізувати ї̈ ступінь та методи впливу на сучасний зовнішній медіапростір людини та суспільства. Завдання статтівивчити та проаналізувати руйнівний зміст реклами та дослідити сочіальний фактор у прочесі комунікаційних процесів суспільства на прикладі інформачії сучасних рекламних повідомлень. Актуальність теми виявляється у необхідності вивчення існування людини в медіа-просторі та їі соціального становлення у віртуальному суспільстві. Зі збільшенням участі людства у віртуальній інформаиійній мережі збільшується ризик неконтрольованості особистості та більша залежність від колективних установок. Вивчається та аналізується сутність соціального фактора від використання деструктивного змісту в рекламному дискурсі, огляду та аналізу деструктивного змісту реклами, ї̈ суб'єктивного змісту та виливу на екзистенційне сприйняття людини світом. Досліджено синергетичний ефект реклами з деструктивними образами в комунікативних соціальних процесах. Досліджено роль формування віртуальних втрат (збитків) у процесі просування товарів та послуг, що використовують руйнівний зміст реклами. Дослідження формування нових ментальних установок одержувачів реклами та їх впливу на існуюче співіснування та взаємодію у суспільстві. У сучасному суспільстві реклама стала важливою частиною соиіалізаиії людей, саме тому вона відіграє значну роль у формуванні гро-

(C) Коваль В. О., 2021 
мадськой думки, оцінках людей та подій, встановленні рівня життя та ставлення до взаємодї̈, в тому числі спрямованої на внутрішній світ особи. Відзначається, щзо через неможливість протидї рекламним зображенням в інформаційному полі людина є споживачем інсталящій, але водночас вона здатна по-різному коригувати наявний вплив і відображати на ньому.

Ключові слова: екзистенцііалізм, комунікація, деструктивний зміст, реклама, сочіальна реклама, ефективність, соичіальна комунікація, інформація, суспільство.

Проблематика використання деструктивних образів негативне тим, що застосування деструктивного змісту з метою забезпечення інформаційних цілей заважає правильному функціонуванню комунікативних процесів соціуму, що призводить до його змін. Стрімкий розвиток постсучасного суспільства сприяє постійному вдосконаленню та збільшенню кількості інформаційних потоків, які існують у соціумі. Наявність деструктивного змісту в масовому інформаційному середовищі впливає на ланку факторів співіснування та взаємодії людей. Самі комунікації всередині суспільства постійно оновлюються та еволюціонують, набувають нових форм та змісту, що виражається у зміні характеристик суспільства та окремо кожної людини. Людина зазвичай не має можливості контролювати рекламний зміст, тому це надає рекламі змогу транслювати будь-який зміст, який своєю чергою має екзистенційний вплив. Рекламна діяльність як різновид комунікації має конструктивний зміст, який створює нові ланки комунікації та розвиває інформаційну забезпеченість суспільства. Одночасно реклама має деструктивну складову, яка заважає коректному та оптимальному функціонуванню комунікативних процесів, а також впливає на світосприйняття людини. Деструктивні образи реклами є сучасним чинником для виконання інформаційних, агітаційних, пропагандистських завдань. Здатність опановувати та оперувати такого роду інформацією надає можливості впливати на зміни всередині соціуму. Оскільки сучасна людина не здатна існувати поза соціумом та глобальним чи локальним інформаційним полем, вивчення деструктивних образів дає змогу дослідити їх вплив на світосприйняття людини та соціуму. Суспільство максимально пов'язане 3 глобаль- 
ною комунікативною мережею. Таким чином, зміни, створені в мережі та продубльовані глобально, регіонально чи навіть поодинично, сприяють швидкій масовій реакції, яка проявляється внутрішньо або зовнішньо. Деструктивні образи існують у зонах сприйняття моралі та естетики індивіда, проте інформаційно їх ефект спрямований на створення штучної картини світу та підміни понять у розумінні своєї екзистенційної природи. Найбільш ефективно деструктивні образи діють на фундаментальні аспекти світосприйняття людини. Вони спрямовані на організацію спотвореного сприйняття світу людиною, зокрема через егоцентричну призму. Власні бажання, комфорт, власне «Я»є найчутливішою ментальною зоною індивіду - таким чином, будь-яке повідомлення, яке проходить через «Я», автоматично стає важливим, незважаючи на зміст. Збільшення чутливості людини до інформаційних подразників збільшує ймовірність іiі керованості ззовні. Цими факторами користуються медіа, компанії, політики тощо. На сьогоднішній день це набуло глобальних, пікових масштабів, що створюють проблему глобального масштабу.

Мета нашої статті полягає у вивченні та аналізі деструктивного змісту реклами, що сприятиме кращому розумінню етапу розвитку сучасних комунікацій (у розділі реклами) та дослідженню соціального фактору в комунікаційних процесах суспільства, на прикладі інформації сучасних рекламних повідомлень.

Теорію дослідження реклами, детериторіалізацію, віртуальність світу, філософське розуміння явища інформації, деструктивний фактор реклами аналізували у своїх працях чимало дослідників, серед яких відзначимо таких, як Ж. Бордіяр, К. Юнг, Ж. Денисюк, О. Злобіна, О. Каріна, Я. Андрушко, А. Акаймова.

Сучасна людина - це складна система організації свідомості, душі, інформації та біологічної складової. Усі складові тісно пов'язані між собою і визначають спосіб соціологічного становлення людини в соціумі. Щодо інформаційної складової, то людина постає як споживач та створювач інформації. Масова поширена діджиталізація та інформаційна експансія закриває всіх індивідів у глобальній інформаційній екосистемі. Віртуалізація суспільства змінює суб'єктивне уявлення та способи внутрішньої комунікації 
між індивідами. Завдяки існуючому дисбалансу між споживанням і створенням інформації, більшість людей є споживачами. Враховуючи поширеність рекламної інформації, іiї однобічний характер та агресивність у медіапросторі, можемо однозначно сказати, що реклама є вагомим фактором впливу на соціологічне становлення людини. Звичайно, без людини реклама не має існування, оскільки вона існує лише у суспільстві, при наявності ії споживачів. Рекламна діяльність, з одного боку, об'єднує суспільство і є корисною для нього, а з іншого - може спричиняти негативний ефект і шкодити і суспільству, і окремим особам.

Особливістю впливу реклами є те, що зовнішній вигляд, зміст і результат реклами можуть бути різні, так і по-різному бути інтерпретовані певною частиною соціуму. Але з погляду загальнолюдських норм і цінностей ми маємо змогу ціннісно виявляти рекламу, яка $є$ конструктивною або деструктивною для суспільства. Світогляд, морально-етичні норми, тенденції та цінності визначають, що саме є корисним соціуму чи індивіду, а що - деструктивним. Унаслідок підміни понять рекламою, це зумовлює зміни в екзистенційному розумінні світу людиною. Фромм визначив п’ять основних екзистенційних потреб людини, а саме: у встановленні стосунків, у подоланні, у вкоріненні, в ідентичності, у системі поглядів та відданості [9, с. 12]. Найбільш стійкі деструктивні поняття змінюють фокус уваги на протилежний, проте задовольняють власні екзистенційні потреби. Прагнення піклуватися про когось змінюються егоїзмом, співчуття - ненавистю. Якщо ця потреба не задовольняється, людина стає нарцисичною, вона обстоює лише свої власні інтереси і не здатна довіряти іншим. Виявлення власної творчості змінюється на придушення думки інших. Неможливість задовольнити самовираження стає причиною людської деструктивності. Прагнення бути в єдності з навколишнім світом змінюється на стигматизацію та егоїзм. Потреба власної ідентичності змінюється на приналежність до певної соціальної групи та прояв неіндивідуальності. Копіюючи чиюсь поведінку, проявляючи сліпу конформність, особистість не здатна досягти почуття власної ідентичності. Потреба у системі поглядів та відданості змінюється на штучні суб'єктивні уявлення про світ. 
Соціологічний ефект реклами полягає в тому, що вона існує в розвиненому суспільстві, де вона $є$ прийнятною. На противагу іншим різновидам комунікації, реклама очікує на двосторонній контакт, комунікацію, яка здійснюватиметься поза межами іiі віртуального існування і нестиме певну користь обом сторонам, на відміну, наприклад, від пропаганди, де комунікація є чітко регламентованою і односторонньою. Захищаючись від масивного інформаційного навантаження, людина обмежує інформаційний вплив реклами ззовні, вважаючи це «білим шумом», що сприяє меншій засвоюваності інформації. Щоб подолати захисні інформаційні баp'єри, рекламна діяльність у комунікативному просторі вдається до використання сильних деструктивних образів та символів, що формують ментальні установки, які, своєю чергою, спричиняють значну суспільну чи персональну реакцію. Таким чином, рекламні повідомлення мають змогу вдало функціонувати в інформаційних потоках суспільства, водночас вливаючи на систему цінностей та поглядів соціуму. Враховуючи те, що реклама заполонила інформаційний простір, з'являється навіть при особистому віртуальному спілкуванні між людьми, деструктивні образи є чинником процесів, що вмотивовано створюють деструктивні зв'язки всередині суспільства, що мають вплив на існуючі культурні, інформаційні, соціальні сфери суспільства.

Спілкування через електронні засоби сприяє тому, що людина як учасник сучасного історичного процесу набуває нових соціально-психологічних характеристик, які відтворюються в усіх співучасників глобального інформаційного простору [7, с. 36]. У сучасних умовах інформаційної війни в Україні дослідження деструктивних образів із соціально-філософської точки зору дає змогу виявити принципи розуміння комунікації сучасного соціуму та сутність комунікативності у суспільстві. Особливістю соціальних реалій стає зростаюча роль масової культури в цілому, і реклами зокрема, а також вплив цих явищ на формування масової і індивідуальної свідомості [2, с. 1].

Важливо розмежувати поняття «деструктивність», «деструктивний результат» і «деструктивний зміст». Деструктивність - це руйнування; абсолютне панування над іншою живою істотою. Де- 
структивний результат - це стан, спричинений діями, який негативно відбивається на об'єкті чи суб'єкті, завдавши йому шкоди. Деструктивний зміст - це повідомлення, оформлене в образ, символ, звук, знак, мета якого - завдати шкоди об'єкту чи суб'єкту.

Деструктивність як явище досліджували зарубіжні і вітчизняні науковці. Серед зарубіжних відзначимо таких дослідників, як Дж. Келлі, Ж.-П. Сартр, К. Роджерс, Е. Фромм, В. Асінгер, К. Лоренц, Л. Берковітц, К. Ізард, які стверджували, що деструктивність, створена людиною, є виявом іiі екзистенціальності та соціальності. Вітчизняні науковці (зокрема Л. Кравченко, Б. Ананьєв, Н. Пряжніков, І. Бойко, Г. Ложкін, Н. Пов'якель, В. Зазикін) тлумачили деструктивні форми по-різному, але більшість 3 них погоджувалась, що це потужний механізм, який призводить до неминучих негативних чинників і завдає шкоди соціуму [3, с. 162].

Зміст будь-якого повідомлення можна передати за допомогою знаків чи образів. Філософ і теолог Августин Аврелій відзначав, що знаком $\epsilon$ щось таке, що вносить у нашу свідомість щось поза собою [1, с. 45]. Деструктивний зміст може містити у собі знаки, що репрезентують його безпосередньо, чи поза собою за допомогою коректної інтерпретації. Навіть використання найменшого символу з деструктивним значенням може легко змінити характер повідомлення та соціальну реакцію на нього. Як приклад, заборонені в Україні символи тоталітарних режимів, що можуть викликати суспільний осуд.

Символ може бути багатозначний. У своїй книзі «Проблеми душі нашого часу» К. Юнг зауважує: «Я аж ніяк не розумію під символом алегорію чи простий знак; швидше я розумію під ним якийсь образ, який повинен, наскільки це можливо, охарактеризувати лише неясно передбачувану природу духу» [10, с. 86]. Символ можна порівняти з кришталем, який пропускає світло під різними кутами, залежно від того, через які грані це світло проходить. Саме багатозначність символу вирізняє різне тлумачення тих чи інших образів, які репрезентуються різними частинами суспільства порізному, або однозначно.

Варто також вирізнити поняття образу у сучасному інформаційному суспільстві. За Бордіяром, поняття образу має багато репрезентацій. Згідно з першим, образ - це доброякісне відображен- 
ня: він показує фундаментальну реальність; згідно з другим, образ $\epsilon$ злоякісним: має шкідливий характер, маскує і спотворює фундаментальну реальність; у третьому випадку образ лише створює вид відображення: характер чародійства, він маскує відсутність фундаментальної реальності; нарешті, у четвертому йдеться вже не про відображення чого-небудь, а про симуляції [4]. Деструктивні образи зазвичай спотворюють реальність або відкривають її справжню сутність. Саме тому заборони чи табуйовані теми певною мірою дають можливість зменшити кількість руйнівних образів для масової свідомості.

Результатом декструктивного змісту прийнято вважати наслідки, які завдали шкоди соціуму в будь-якому виді: фізичному, ідеологічному, економічному, екологічному, культурному тощо. У комунікативному полі суспільства деструктивність є полем постійного зіткнення та узгодження інтересів різних сторін. Його негативний вплив полягає у «зламі» особистості, стимуляція безсилля хоч би що зробити, а на рівні соціуму - демотивує, провокує, вводить у конфліктний стан самим із собою.

На противагу руїнному є конструктивний зміст, який, навпаки, є корисним. Конструктивний зміст позитивно впливає на особистість, забезпечує іiі подальший розвиток, допомагає повірити у себе і в людей. На рівні соціуму він позитивно впливає на процеси та стан суспільства.

Деструктивний зміст може проявлятися в усіх видах реклами: у соціальній, політичній та комерційній. Його негативний вплив не відміняє цілі рекламного повідомлення і виконує свою мету, а саме - просунути товар чи послугу. Результатом використання деструктивного змісту реклами є зміна цінностей соціуму й індивіда загалом. Деструктивні образи поглиблюють егоцентричність людини, роблячи її менш соціальною. Наприклад, сучасні тенденції десоціалізації суспільства та його віртуалізації: діджиталізація, соціальні мережі, соціальна ізоляція, перехід на віртуальне спілкування замість реального, збільшення частки ринку онлайнпокупок тощо.

Відзначимо, що у сучасному інформаційному середовищі найбільший вплив рекламні повідомлення мають у віртуальному 
світі - мережі. О. Каріна наголошувала, що поняття віртуальної реальності застосовують як синонім для означення уявного, умовного, удаваного, фіктивного, симулятивного, потенційно можливого, яке, $з$ одного боку, не $є$ спостережуваним, а 3 іншого - позначає дійсне, фактичне, візуально представлене [8, с. 3]. С. Коноплицький зауважував, що віртуальне спілкування можна розглядати на рівні реального, за винятком таких елементів, як міміка, жести, інтонації [7, с. 34]. Існуючи в інформаційному віртуальному середовищі, рекламна комунікація оперує образами та символами, серед яких є конструктивні та деструктивні.

Із метою кращого розуміння дестуктивізму в рекламі варто звернути увагу на семіотичну складову рекламної комунікації. Образна та знакова системи дають можливість краще осягнути повідомлення для споживача та простежити за їхньою соціальною дією. Семіотика реклами припускає наявність і розгляд різних варіантів аналізу рекламного повідомлення. Це дає змогу з'ясувати структуру і семантику реклами, усвідомити, на чому заснований іii ефект сугестії, а також сконструювати власний рекламний текст, спираючись на його структурні розділи, самостійно аналізувати той або інший тип рекламного повідомлення, виявляючи в ньому переваги і недоліки [2, с. 2].

До деструктивного змісту можна зарахувати: образи, символи та повідомлення, що виражають агресивність, конфлікти (внутрішньо особистісний, міжособистісний тощо), антисоціальну тематику (сексизм, расизм, тероризм, фашизм), контент для дорослих, психоделіку, насилля, жорстоке поводження 3 дітьми, заклики до нищення, розділення, залякування, відчаю, алкоголізм, наркоманію, суїцид, тютюнопаління, яке завдає шкоди соціуму у будьякому прояві. На сьогодні в Україні можна спостерігати незначний відсоток рекламних повідомлень, які знаходяться в публічних місцях чи в інтернет-мережах. Їх існування забезпечує зростання суспільної реакції на них, та власне, закріплення месседжу у масовій свідомості.

Як приклад, використання образів прояву сексизму та гендерної нерівності. Іноді рекламодавці вмотивовано або невмотивовано публікують рекламні образи та повідомлення, спрямовані на виникнення різних стереотипів сексизму, зокрема: «жінка- 
прибиральниця», «жінка-посудомийка», «жінка-об'єкт для задоволення чоловічих сексуальних бажань» тощо. Наприклад, реклама страхування автомобілів від «Альфа-страхування»: «Купив «німкеню»? Застрахуй іï швидко та без прелюдій», «Купив «японку»? Застрахуй ï без церемоній», ««Американки» люблять велике Каско», «Холодних «шведок» заводить гаряча ціна». Ці слогани супроводжуються зображеннями жінок із сексуальним підтекстом. Так, відома мережа заправних станцій «ОККО» не втрималася від проведення невигадливих аналогій між машиною і жінкою: «Люблю, коли вона заводиться...». Іншими прикладами можна розглянути товари різних брендів «для нього» та «для неї», де експлуатуються стереотипні сексистські образи. Особливо яскравим прикладом є експлуатування жіночого питання в політичній рекламі президентської кампанії 2019 року: «2019. Останній шанс для бабусі», вказуючи на одного з кандидатів та водночас звернення до стереотипу, що «бабусі» - це пенсіонери, які голосують на виборах за матеріальні продукти.

Деструктивний результат даних повідомлень полягає в розпалювані внутрішньосоціальних конфліктів та закріпленні певного ставлення до суб'єктів соціуму. Так, на тлі гендерної нерівності, усунення жінок від процесу планування, розробки і ухвалення політичних рішень негативно позначається на реалізації рішень, на впровадженні збалансованої стратегії розвитку суспільства 3 урахуванням інтересів чоловіків та жінок, дітей, гармонійного розвитку сімейних відносин тощо [5, с. 104]. У глобальних масштабах використання деструктивного змісту може впливати на масову культуру та свідомість.

Деструктивні образи та символи, які існують всередині системи міжлюдських відносин, та безліч каналів комунікації поодиночно але системно вносять зміни у соціальну систему комунікацій. Суб'єкти, які поширюють деструктивні образи, несуть загрозу інформаційно-психологічній безпеці особистості. Сучасний інформаційний простір, що переважно формується масовою культурою, значно розширює свої межі за рахунок інтернет-мережі, яка докорінно змінила світогляд людини, ії самоусвідомлення та й загалом знаково-символічні коди культури [6, с. 9]. За допомогою реклам- 
ної комунікації соціум має змогу пізнавати власні соціальнокультурні можливості, організовувати процес внутрішнього розвитку та соціальної взаємопідтримки. Сприятливим середовищем для реалізації таких потреб стала віртуальна реальність, яка є особливим типом вербально-візуальної і комунікаційної системи та визначає нові засади існування культури й людини в ній. Віртуальність занурює людину у знаково-символічний простір, створюючи можливості не лише для безмежної комунікації, знаходження інформації, а й для долучення до віртуальних спільнот за інтересами, для пізнання власного «Я», формуючи тим самим окремий тип (субкультуру) віртуального простору (мережі) [6, с. 10].

Висновок виражає негативність явища деструктивного змісту, що руйнівно впливає на екзистенційні основи співіснування та взаємодії людей. У сучасному суспільстві реклама стала суттєвою частиною соціалізації людей, вона відіграє значну роль у формуванні суспільної думки, оцінок людей та подій, задаючи стандарти життя та свідомості. Зазвичай, зміст реклами визначає соціальну реакцію на неї та наслідки з цього. Глобально, це змінює суспільні уявлення та світогляд. Враховуючи сучасні тенденції розвитку, десоціалізації та віртуалізації суспільства, деструктивні образи $є$ площиною для зіткнення інтересів, конфліктів тощо. Серед великої кількості інформаційних повідомлень промоційного характеру $є$ незначний відсоток деструктивного змісту, що завдає шкоди суспільству. Проте внаслідок його активного збільшення, дана проблематика здатна створювати зміни, виправляти які доведеться кільком поколінням. Усі прояви руїнного змісту в рекламі впливають на глобальне інформаційне поле, що своєю чергою формує суспільство. Внаслідок неможливості протидіяти рекламним образам в інформаційному полі людина здатна сама коригувати існуючий вплив та рефлексувати на нього по-різному. Деструктивність має значний вплив у зонах сприйняття моралі та естетики індивіда, що посилюється сучасними соціальними та технічними інструментами. Їх ефект значно змінює створення штучної картини світу та підмінюе поняття в розумінні екзистенційної природи людини, що робить дану проблему актуальною для подальших досліджень. 


\section{ЛITЕРАТУРА}

1. Deely John. Basics of Semiotics. Toronto, 1990. 149 p.

2. Акайомова А. В. Семіотична модель комунікації реклами. Науковий вісник. Збірник наукових праџь ВІР УАН. 2011. 367 с.

3. Андрушко Я. С. Теоретичний аналіз деструктивних форм поведінки індивіда під час здійснення особистісного. Науковий вісник Львівського державного університету внутрішніх справ. Серія психологічна. 2016. Вип. 2. С. 160-169.

4. Бодрийяр Ж. Симулякры и симуляиии. Москва, 2015. 240 с.

5. Гендерні медійні практики: Навчальний посібник із гендерної рівності та недискримінації для студентів вищих навчальних закладів. Київ, 2014. 206 с.

6. Денисюк Ж. 3. Віртуальність масової культури як поле конструювання уявних ідентичностей. Вісник Національної академії керівних кадрів культури і мистецтв. 2016. № 1. С. 8-12.

7. Злобіна О. «Екранна версія» життя і зміни особистісної суб’єктивності. Соиіологія: теорія, методи, маркетинг. 2002. № 2. С. 33-37.

8. Каріна О. М. Віртуальна реальність: онтологічний статус. Харків, 2004. 17 с.

9. Фромм Э. Бегство от свободыл. Москва, 1989. 272 с.

10. Юнг К. Г. Проблемы души нашего времени. СПб., 2017. 336 с.

\section{REFERENCES}

Deely, J. (1990). Basics of Semiotics. Toronto.

Akayomova, A. (2011). Semiotic model of advertising communication. Scientific Bulletin. Collection of scientific works VIR UAS. [In Ukrainian].

Andrushko, J. (2016). Theoretical analysis of destructive forms of individual behavior during the implementation of personal. Scientific Bulletin of Lviv State University of Internal Affairs. The series is psychological, 2, 160-169. [In Ukrainian].

Baudrillard, J. (2015). Simulacra and simulations. Moscow. [In Russian].

Gender Media Practices: A Textbook on Gender Equality and NonDiscrimination for Higher Education Students. (2014). Kyiv. [In Ukrainian]. 
Denisyuk, Zh. (2016). Virtuality of mass culture as a field of constructing imaginary identities. Bulletin of the National Academy of Management of Culture and Arts, 1, 8-12. [In Ukrainian].

Zlobina, O. (2002). «Screen version» of life and changes in personal subjectivity. Sociology: theory, methods, marketing, 2, 33-37. [In Ukrainian].

Karina, O. (2004). Virtual reality: ontological status. Kharkiv, 17 p. [In Ukrainian].

Fromm, E. (1989). Escape from freedom. Moscow, 272 p. [In Russian].

Jung, K. (2017). Problems of the soul of our time. St. Petersburg, 336 p. [In Russian].

\title{
Vitalii Koval
}

Post-Graduate Student, the Department of Philosophy, Zhytomyr State University named after Ivan Franko; Zhytomyr, Ukraine; e-mail: vtalij.koval.kvo@gmail.com; ORCID: https://0000-0002-7469-4119

\section{Destructive content of advertising: images and symbols (socio-philosophical aspect)}

\begin{abstract}
The study of the destructive content of advertising allows us to analyze its degree and methods of influencing the modern external media space of man and society. The task of the article is to study and analyze the destructive content of advertising and to explore the social factor in the process of communication processes of society, on the example of information of modern advertising messages. The relevance of the topic is manifested in the need to study the existence of man in the media space and its social formation in a virtual society. With the increasing involvement of humanity in the virtual information network increases the risk of uncontrollability of the individual, and greater dependence on collective attitudes. The essence of the social factor from the use of destructive content in advertising discourse, review and analysis of the destructive content of advertising, its subjective content and the impact on the existential perception of man by the world are studied and analyzed. The synergetic effect of advertising with destructive images in communication social processes is investigated. The role of formation of virtual losses (damage) in the process
\end{abstract}


of promoting products and services that use the destructive content of advertising has been studied. Research of formation of new mental attitudes of recipients of advertising and their influence on existing coexistence, and interaction in a society. In modern society, advertising has become an essential part of the socialization of people, which is why it plays a significant role in shaping public opinion, evaluations of people and events, setting living standards and attitudes of interaction, including those aimed at the inner world of the individual. Due to the impossibility to counteract advertising images in the information field, a person is a consumer of installations, but at the same time he is able to correct the existing influence and reflect on it in different ways. The degree of development of the problem is described in the main presentation of the article.

Keywords: existentialism, communication, destructive content, advertising, social advertising, efficiency, social communication, information, society. 